\title{
Strategies and Clinical Implications of Chimerism Diagnostics after Allogeneic Hematopoietic Stem Cell Transplantation
}

\author{
Christian Thiede Martin Bornhäuser Gerhard Ehninger \\ Medizinische Klinik und Poliklinik I, Universitätsklinikum Carl Gustav Carus der Technischen Universität, \\ Dresden, Germany
}

\section{Key Words}

Stem cell transplantation - Chimerism - Minimal residual disease $\cdot$ PCR $\cdot$ Leukemia

\begin{abstract}
Analysis of donor chimerism has become a routine method for the documentation of engraftment after allogeneic hematopoietic stem cell transplantation (HSCT). In recent years several groups have also focused on the application of this technique for the detection of relapsing disease after allogeneic HSCT. This review addresses technical issues (sensitivity, specificity) and discusses the advantages and limitations of methods currently used for chimerism analysis and their usefulness for the detection of MRD. In addition, the potential impact of novel procedures, e.g. subset chimerism or real-time PCR-based procedures, is discussed.
\end{abstract}

Copyright ( 92004 S. Karger AG, Basel

\section{Introduction}

After allogeneic blood stem cell transplantation, a coexistence of the host and donor lympho- and hematopoietic system will develop. This period, which is temporary in the majority of successful stem cell transplants, is referred to as mixed chimerism, whereas complete chi- merism denotes the situation, when all cell lineages are reconstituted by the donor. The evaluation of chimerism after stem cell transplantation has been of central interest since this treatment has been used clinically. Several techniques have been applied for this purpose during the last 30 years, including cytogenetics, isoenzyme analysis and blood group phenotyping [for a review, see 1]. A major improvement in the clinical applicability was made when differentiation of sex chromosomes using fluorescence in situ hybridization (FISH) became possible $[2,3]$. This method allows rapid and quantitative evaluation of engraftment; however, it is obviously restricted to the approximately $50 \%$ of patients transplanted from a sex-mismatched donor. The invention of the polymerase chain reaction (PCR) was a key step which laid the fundament for the development of modern molecular diagnostics [4]. In the field of chimerism diagnostics, several PCR-based procedures have been developed for the evaluation of engraftment [5-16]. Most of these assays rely on the amplification of highly polymorphic repetitive DNA sequences, i.e. short tandem repeats (STR) or a variable number of tandem repeat (VNTR) sequences.

Besides the documentation of engraftment, detection of reappearing leukemic cells has become a key issue in chimerism diagnostics. Numerous publications deal with this application. This review focuses on the use of chimerism analysis for the detection of minimal residual leuke-

\section{KARGER}

Fax +41613061234

E-Mail karger@karger.ch

www. karger.com
(C) 2004 S. Karger AG, Basel

0001-5792/04/1122-0016\$21.00/0

Accessible online at:

www. karger.com/aha
Christian Thiede, MD

Medizinische Klinik und Poliklinik I

Universitätsklinikum Carl Gustav Carus der Technischen Universität

Fetscherstrasse 74, DE-01307 Dresden (Germany)

Tel. +49 351458 4704, Fax +49 351458 5362, E-Mail thiede@mk1.med.tu-dresden.de 
Table 1. Comparison of different methods for chimerism analysis

\begin{tabular}{llll}
\hline Method & Sensitivity ${ }^{1} \%$ & Advantages & Disadvantages \\
\hline XY-FISH & 0.1 & $\begin{array}{l}\text { Quantitative relatively sensitive, } \\
\text { fast, standardized technique }\end{array}$ & Restricted to sex mismatch \\
\hline Real-time PCR & $0.1-0.0001$ & Quantitative, highly sensitive & $\begin{array}{l}\text { False positive results possible in } \\
\text { SNP-based procedures }\end{array}$ \\
\hline Red cell phenotyping & & Fast sensitive & $\begin{array}{l}\text { Long latency makes it unsuitable for } \\
\text { rapidly proliferating diseases }\end{array}$ \\
\hline STR or VNTR-PCR & $5-1$ & $\begin{array}{l}\text { Informative, low amounts of } \\
\text { material, rapid }\end{array}$ & Moderate sensitivity \\
\hline $\begin{array}{l}\text { YX-FISH and immuno- } \\
\text { histochemistry (FICTION) }\end{array}$ & $0.1-0.001$ & Sensitive, cell line specific & $\begin{array}{l}\text { Labour intensive, restricted to sex } \\
\text { mismatch }\end{array}$ \\
\hline $\begin{array}{l}\text { STR-PCR + cell sorting } \\
\text { DT }\end{array}$ & $0.1-0.0001$ & Sensitive, cell line specific & $\begin{array}{l}\text { Labor intensive, requires specific } \\
\text { equipment }\end{array}$
\end{tabular}

* The lower level of host cells detectable is denoted.

mia and addresses several questions which may be important in this context: (1) Are the current methodologies for chimerism analysis appropriate for the detection of minimal residual disease (MRD)? (2) If so how can they potentially be further improved? (3) If not, which alternatives can be found to sufficiently solve the problem?

\section{Methods for Chimerism Analysis and Their Sensitivity}

The first of these questions is especially important. The term MRD describes a state of leukemic burden which is below the threshold detection level of conventional measures, i.e. morphology. This standard method for assessment of response towards chemotherapy has, by definition, a limit of detection for leukemic blasts in the bone marrow of 5\% [17]. Thus any procedure which can measure cells below this level may be suitable to detect leukemic cells. But what level of sensitivity should we approach? Generally one might wish to know precisely which level of MRD has been reached. Thus, it is much more important to quantitatively assess the level of residual leukemia than to deal with merely qualitative analyses. The level of detection achievable can be illustrated by comparing several techniques which are currently used for the detection of residual leukemia after treatment. For example, FISH detection of chromosomal translocations has a level of sensitivity between 0.1 and $8 \%$ depending on the technique used and the specific translocation investigated [recent review in 18]. Flow-cytometric assays, monitoring aberrant antigen expression, might achieve considerably higher levels of sensitivity, between 0.01 and $1 \%$ [recent examples in 19, 20]. PCR, however, represents the most sensitive technique reported so far. The exponential amplification of specific target sequences facilitates a limit of detection between 0.1 and $0.01 \%$ cells. This sensitivity can be further increased if two consecutive rounds of PCR are applied, which routinely detects $1 / 10^{5}$ to $1 / 10^{6}$ cells, and which can be further increased and has been used even to demonstrate the presence of leukemia-associated translocations in healthy individuals [21]. The diagnostic message can be substantially augmented when quantitative PCR methods (realtime PCR) are applied, which gives information on the number of starting molecules [22]. Thus, taken together there is a broad range of methods for the detection of residual leukemia. The methods currently in use for chimerism analysis must be interpreted in this context, if discussing their value in the detection of MRD. Table 1 summarizes different techniques for chimerism analysis, their advantages and disadvantages as well as the reported levels of sensitivity.

Among these assays, STR-based methods are the most frequently used. These methods usually have a level of sensitivity between 1 and 5\%, a range which allows the accurate and reliable monitoring of engraftment. In addition, there is evidence that at least in slowly proliferating 
diseases like CML, this level may be sufficient for the routine follow-up. Several reports have shown that increasing mixed chimerism is a sensitive predictor of relapse in cases with persistent positivity for the bcr-abl fusion transcript [35, 36]. However, these data mainly originate from the era before real-time PCR for the bcr-abl mRNA has become widely available [37]. Today, the quantitative information on the bcr-abl copy numbers is regarded as the most important diagnostic tool in this disease [for a review, see 38]. Nevertheless, chimerism analysis may be an important adjunct method to assess the response towards donor leukocyte infusion (DLI) [30, 32]. In addition, analysis of chimerism in bone marrow CD34+ cell before DLI may give valuable information on the risk of developing aplasia after DLI [39]. Chimerism analysis in transplant settings using $\mathrm{T}$ cell depletion to schedule $\mathrm{T}$ cell add-back and to monitor the success of this intervention may also be of special importance, especially in transplants with dose-reduced conditioning [40].

Conflicting data have been reported on the question of whether standard STR-based procedures are also useful for the early detection of reappearing disease in acute leukemias. There are several reports indicating that a level of about $1 \%$ may be sufficient to detect relapse in acute leukemia. Bader et al. [41] described the use of overall chimerism analysis in 30 transplanted children with acute lymphoblastic leukemia (ALL), acute myeloid leukemia (AML) and MDS. Patients who showed mixed chimerism had a significantly higher probability of relapse compared to those with stable complete chimerism. However, there were also patients within this cohort who had increasing host chimerism without relapse as well as 3 patients who had complete chimerism before relapse. A later analysis by the same group of 55 patients confirmed these data [42]. Similar data, indicating that chimerism analysis from unsorted peripheral blood or bone marrow samples is able to detect relapse, were published by several groups $[43,44]$. In contrast, other groups were not able to demonstrate a good prediction of relapse by analyzing chimerism from the peripheral blood. Suttorp et al. [9] showed that an RFLP assay with a $1 \%$ sensitivity showed complete chimerism 30-86 days before a clinical relapse was diagnosed. They concluded that the kinetics of reappearing leukemia are too rapid to be diagnosed with a detection limit of $1 \%$. Comparable results were seen by other groups [45-48]. Taking these results together, mixed chimerism may precede subsequent relapse, but the interval between the decrease in donor cells using STR or VNTR-PCR and the clinical diagnosis is much too short to make meaningful clinical decisions in the majority of the patients. The background of these discrepancies in the reports on the usefulness of chimerism analysis of peripheral blood is not yet clear. The reasons may be technical (e.g. different levels of sensitivity) or different sampling protocols. They may also be related to different patient populations, since the majority of data showing sufficient sensitivity are from pediatric transplantations. However, an increase in sensitivity is clearly desirable to improve the detection range of residual host cells and to potentially increase the time for clinical decision making.

\section{New Techniques for the Detection of MRD Using Chimerism Analysis}

As stated above, STR-based methods have a level of sensitivity which is in the range of $1-5 \%$. One additional problem associated with this technique is the diagnostic uncertainty induced by PCR artifacts (stutter signals) [49], which renders a large number of peak constellations insufficient for analysis, because a residual host signal is located within the stutter peak of the donor, and thus cannot be detected accurately [50]. To overcome this limitation, a selection of STRs with a high proportion of donor/ recipient constellations without interference of host and donor signals is desirable. In a recent analysis of 27 different STRs in a population of 203 HLA-matched related donors and recipients, we have identified a subset of markers with a high likelihood of finding such constellations [50a]. However, even if STR-based assays for chimerism analysis may be further improved and may detect leukemic cells in some patients, according to our experience and most of the published data the detection is too late in most of the patients to facilitate early intervention, e.g. tapering of immunosuppressive therapy. Thus in order to detect recurring disease as early as possible, novel assays with higher sensitivity would be a major improvement. Recently, quantitative chimerism analysis using real-time PCR has been reported for this purpose. Realtime PCR, either by the 5'-nuclease assay (TaqMan procedure) or by fluorescent resonance energy transfer, has the advantage that the product yield of the PCR is measured during each cycle, which allows the calculation of the number of starting molecules [for a review, see 22]. Realtime PCR monitoring has become a standard procedure for the evaluation of the response to therapy in acute and chronic leukemias and has been shown to be a sensitive and predictive tool for the guidance of treatment. It relies on the amplification of a specific target sequence, such as fusion oncogenes (e.g. bcr-abl, PML-RARalpha) or B or 
T cell receptor rearrangements [22]. However, in a large proportion of acute leukemias, such specific molecular targets are missing. In male patients transplanted from a female donor, the $\mathrm{Y}$ chromosome represents a unique characteristic of recipient cells. Lo et al. [51] were the first to use real-time PCR for the SRY gene on the Y chromosome to detect microchimerism due to fetomaternal transfer in females who have given birth to male children. Fehse et al. [23] have reported a similar method for the evaluation of chimerism after hematopoietic stem cell transplantation (HSCT). However, clinical data on the use of this procedure are still missing. We used real-time PCR for the SRY gene on the Y chromosome to quantify the level of chimerism in 43 male patients transplanted from a female donor [52]. This method was shown to have a lower limit of detection of one male cell in 100,000 female cells. Our results indicate that residual host cells are detectable at very low levels in almost all patients investigated up to 5 years after transplantation. In addition, a gradual decrease of residual host cells was found over time (median 1 month: $0.3 \%$; median 6 months: $0.01 \%$; median 1 year: $0.0061 \%$; median 4 years: $0.0015 \%)$. This persistence of host cells over long periods at low levels might explain why earlier reports using end point PCR did not show any impact of the detection of residual host cells [53]. In contrast, using real-time PCR, patients with relapse showed an increase in the percentage of host cells which preceded the haematological relapse by up to 120 days. Thus, real-time PCR might represent an interesting tool to analyze the level of residual host cells. As discussed earlier, the $\mathrm{Y}$ chromosome can be used only in a subset of patients. Several groups have now reported real-time PCR assays using other genetic targets, i.e. single nucleotide polymorphisms (SNPs), for the differential amplification of host cells after transplantation. SNPs are mostly biallelic genetic variances which occur on average every $1,000 \mathrm{bp}$, thus about $3,000,000$ of these polymorphisms are present. Alizadeh et al. [54] recently published a set of 11 biallelic SNPs for real-time PCR analysis after allogeneic HSCT. These SNPs could discriminate $90 \%$ of the donor and recipient constellations tested. The assay has a minimum sensitivity of $0.1 \%$, which is not as sensitive as for the SRY gene, but at least 10-fold better than for standard STR or VNTR-based methods. Maas et al. [25] also published data on the use of real-time PCR for chimerism analysis with very similar results. In summary, real-time PCR-based procedures will provide an important improvement of the diagnostic inventory for chimerism analysis. However, as shown by several authors, realtime PCR cannot totally replace STR- or VNTR-based methods. One substantial drawback of this technique is the lower quantitative accuracy $[25,54]$. This problem is inherent in the technique, since a change of only one PCR cycle means a 2-fold quantitative difference. This implies that a coefficient of variation of about $20-30 \%$ must be considered as normal. In contrast, STR-based procedures, especially when performed in a multiplex PCR, achieve reproducibility values between 4 and $8 \%[50,55]$. Thus in states of chimerism exceeding 5\% host signal, STR analysis remains the method of choice. This technique is also superior to real time in the analysis of subset populations due to the limitations discussed above.

Another possibility to increase the sensitivity of a chimerism analysis is the use of specific subpopulations of the peripheral blood or bone marrow. The enrichment of cellular compartments has been shown to increase the sensitivity of chimerism analysis, since specific populations of cells, like B cells, T cells or early stem cells, are enriched from the background of mature granulocytes. Ginsburg and coworkers [56] were the first who described the investigation of cellular subsets after HSCT; van Leeuwen et al. [57] were the first to use highly purified cellular populations. Meanwhile, several groups have reported the analysis of chimerism in specific subsets to detect reappearing leukemic cells $[27,34,58-61]$ or to monitor the effect of treatment [30].

Lamb et al. [58] described the use of subset analysis to differentiate suspicious relapse in two cases. In one patient they did not find evidence for relapse, whereas the second patient showed relapse in the CD34+/CD7+ leukemic cells, which was undetectable in the unsorted bone marrow material. Zetterquist et al. [60] compared chimerism analysis in sorted B cells with overall chimerism and PCR for clone specific T cell or B cell receptor rearrangements. Mixed chimerism in the B cell compartment was found in 5 patients who also showed persistence of the clonality marker in the PCR. Mixed chimerism in the B cells was detected 2.5 months prior to the morphological relapse in $3 / 4$ patients with relapse. No relapse was observed in those seven cases with complete donor chimerism in the B cell compartment. Mattson et al. [34] studied 30 patients with AML and MDS. They used immunomagnetic labeling with antibodies against CD33, CD7 or CD45 to enrich the specific subpopulations from the peripheral blood or the bone marrow, achieving a final sensitivity between 2 and $4 \times 10^{-4}$. Mixed chimerism in these populations 1 month after transplantation was observed in 14 of the 30 patients. A relapse was seen in 10/ 14 patients with mixed chimerism in the subpopulations compared to only $2 / 16$ cases with complete chimerism, a 
difference which was highly significant. Interestingly, mixed chimerism in the peripheral blood seemed to have a lower sensitivity (67\%), but a higher specificity $(100 \%)$ in the prediction of relapse compared to the analysis of bone marrow samples.

We have recently performed a study using CD34+ cells as target for the identification of leukemic cells. The basic idea behind this was that the CD34 antigen is expressed on a very small population of normal hematopoietic progenitor cells, but can be frequently detected on blasts of different leukemias $[62,63]$. Evaluation of this method showed a minimum sensitivity of $1 / 40,000$ cells [33]. In a panel of 87 prospectively investigated patients, chimerism analysis in the CD34+ cells was performed for the detection of relapse [61]. After a median follow-up of 295 days (range 28-1,152 days), a total of 22 relapses were observed in the 84 patients showing engraftment. Relapse was associated with a decrease in CD34+ cell donor chimerism by up to 97 days in 20/22 patients. In patients with CML and molecular relapse, recurrent disease was associated with a decrease in donor CD34+ cells. Treatment with DLI or imatinib resulted in an increase in donor CD34+ cells and a clearance of bcr-abl-positive cells. Since this assay can be performed with peripheral blood, the investigations can be done at short intervals. These data inspired us to start a randomized prospective multicenter trial comparing chimerism from the peripheral blood and subset chimerism within the CD34 compartment in patients with AML, ALL or MDS whose leukemia blasts express the CD34 antigen. In patients showing a decrease in the proportion of donor CD34+ cells below $60 \%$, immunosuppression is reduced or DLIs are given. First results of this study are inspiring and we have seen responses in several cases of AML and ALL.

Thus taken together, these data clearly show that subset analysis is a very sensitive technique, with a limit of detection comparable to nested PCR. This technique adds important information, since it is able to clarify whether reappearing host cells are of leukemic origin or are $\mathrm{T}$ cells or other nonmalignant cells.

In this article we have not focused specially on the use of chimerism in the setting of dose-reduced conditioning, since the detection of MRD is not substantially different after this form of transplantation. However, since mixed chimerism, especially in $\mathrm{T}$ cells, is much more common after dose-reduced preparative regimens, subset analysis is even more important to differentiate persistent mixed $\mathrm{T}$ cell chimerism from reappearing leukemic cells.

\section{Use of Chimerism for Follow-Up after Transplantation: The Dresden Experience}

Recently, several groups have published their procedures for the follow-up investigations after allogeneic HSCT [64-69]. These reports are mainly focused on technical issues. As discussed above these questions are certainly important. However, especially for the detection of MRD, the use of the appropriate methods according to the clinical situation is most important. Based on our own experience and the literature data, our current recommendations for chimerism analyses are as follows: During engraftment and during the entire period of mixed macrochimerism (i.e. chimerism between 3 and 97\%), STR analysis, preferentially in a multiplex assay, should be used on whole blood or bone marrow samples to quantify chimerism. We usually perform these analyses twice weekly starting at day +5 . If graft failure or relapse is clinically suspected, sorting of T cells, NK cells and myeloid cells, preferentially CD34+ cells, might be helpful. Once the chimerism in the peripheral blood has reached a level of more than $97 \%$ donor, real-time PCR assays should be used for further monitoring whenever possible. When real-time PCR indicates that the level of residual host cells further declines follow-up monitoring with real-time PCR is recommended at regular intervals. When this method indicates a level of residual host cells below $0.005 \%$, the periods between the analyses may be increased to 2-3 months, because up to now we have not seen relapses when patients were at this low level. When real-time PCR assays cannot be used, standard STR-PCR should be performed at closer intervals. The length of the intervals should be chosen according to the tendency of relapse of the primary disease and the time after transplantation, with more frequent analyses (weekly to every 2 weeks) performed in patients with high risk disease (like AML or ALL) and early after transplantation. This very tight schedule should be followed for the first 2 years after transplantation, since the majority of relapses occur during this period. If real-time PCR shows that the level of host cells does not decline or increases again, subset analysis (including T cells, CD15+ cells and, if possible, CD34+ cells) should be performed in order to clarify the origin of these cells. Based on this information and the clinical situation (i.e. whether there is graft versus host disease present or not and the individual relapse risk), reduction of the immunosuppressive therapy or infusion of $\mathrm{T}$ cells might be performed.

Thus in conclusion, we believe that chimerism analysis can be performed for the detection of MRD, but the

\footnotetext{
$\overline{20} \quad \overline{\text { Acta Haematol 2004;1 12:16-23 }}$
} 
diverse methods currently available differ in their abilities. If there is a genetic marker (translocation, IgVH rearrangement) which can be used for real-time PCR, this is certainly the first choice for MRD detection, since these markers are specific for leukemia. If not, chimerism analysis using the most sensitive and quantitative method available should be used. We believe that a strategy like this will allow for a more accurate and reliable assessment of chimerism and might help to identify patients at risk of a reappearance of leukemia. However, prospective trials will clearly have to show whether these strategies can be used to achieve a longer leukemia-free survival after transplantation.

\section{Acknowledgments}

This study was supported in part by the Deutsche Krebshilfe, Bonn (grant No. 70-2755 to CT and MB).

\section{References}

1 Bryant E, Martin PJ: Documentation of engraftment and characterization of chimerism following hematopoietic cell transplantation; in Thomas ED, Blume KG, Forman SJ (eds): Hematopoietic Cell Transplantation. Oxford, Blackwell Science, 1999, pp 197-206.

2 Durnam DM, Anders KR, Fisher L, O'Quigley J, Bryant EM, Thomas ED: Analysis of the origin of marrow cells in bone marrow transplant recipients using a Y-chromosome-specific in situ hybridization assay. Blood 1989;74:22202226.

3 Wessman M, Ruutu T, Volin L, Knuutila S: In situ hybridization using a Y-specific probe - A sensitive method for distinguishing residual male recipient cells from female donor cells in bone marrow transplantation. Bone Marrow Transplant 1989;4/3:283-286.

4 Saiki RK, Scharf S, Faloona F, Mullis KB, Horn GT, Erlich HA, Arnheim N: Enzymatic amplification of beta-globin genomic sequences and restriction site analysis for diagnosis of sickle cell anemia. Science 1985;230: 1350-1354.

5 Lawler M, Humphries P, McCann SR: Evaluation of mixed chimerism by in vitro amplification of dinucleotide repeat sequences using the polymerase chain reaction. Blood 1991;77: 2504-2514.

6 Ugozzoli L, Yam P, Petz LD, Ferrara GB, Champlin RE, Forman SJ, Koyal D, Wallace RB: Amplification by the polymerase chain reaction of hypervariable regions of the human genome for evaluation of chimerism after bone marrow transplantation. Blood 1991;77:16071615 .

7 Gaiger A, Mannhalter C, Hinterberger W, Haas O, Marosi C, Kier P, Eichinger S, Funovic $M$, Lechner $K$ : Detection of engraftment and mixed chimerism following bone marrow transplantation using PCR amplification of a highly variable region-variable number of tandem repeats (VNTR) in the von Willebrand factor gene. Ann Hematol 1991;63/4:227-228.

8 Roux E, Helg C, Chapuis B, Jeannet M, Roosnek E: Evolution of mixed chimerism after allogeneic bone marrow transplantation as determined on granulocytes and mononuclear cells by the polymerase chain reaction. Blood 1992 ; 79:2775-2783.
9 Suttorp M, Schmitz N, Dreger P, Schaub J, Loffler H: Monitoring of chimerism after allogeneic bone marrow transplantation with unmanipulated marrow by use of DNA polymorphisms. Leukemia 1993; 7:679-687.

10 Harano H, Maruta A, Matsuzaki M, Kanamori H, Fukawa H, Noguchi T, Miyashita H, Ogawa K, Motomura S, Kodama F: Evaluation of chimerism after bone marrow transplantation with single locus minisatellite DNA probes. Bone Marrow Transplant 1993;12/3:221-224.

11 Martinelli G, Trabetti E, Zaccaria A, Farabegoli P, Buzzi M, Testoni N, Calori E, Bandini $\mathrm{G}$, Rosti $\mathrm{G}$, Belardinelli A: In vitro amplification of hypervariable DNA regions for the evaluation of chimerism after allogeneic BMT. Bone Marrow Transplant 1993;12/2:115-120.

12 Oberkircher AR, Strout MP, Herzig GP, Fritz PD, Caligiuri MA: Description of an efficient and highly informative method for the evaluation of hematopoietic chimerism following allogeneic bone marrow transplantation. Bone Marrow Transplant 1995; 16:695-702.

13 Kogler G, Hernandez A, Heyll A, Wolf HH, Wernet P: Qualitative assessment of mixed chimerism after allogeneic bone marrow transplantation with regard to leukemic relapse. Cancer Detect Prev 1996;20:601-609.

14 Briones J, Urbano-Ispizua A, Rozman C, Marin P, Carreras E, Rovira M, Sierra J, Colomer D, Martinez C, Montserrat E: Study of hematopoietic chimerism following allogeneic peripheral blood stem cell transplantation using PCR amplification of short tandem repeats. Ann Hematol 1996;72/4:265-268.

15 Elmaagacli AH, Beelen DW, Becks HW, Mobascher A, Stockova J, Trzensky S, Opalka B, Schaefer UW: Molecular studies of chimerism and minimal residual disease after allogeneic peripheral blood progenitor cell or bone marrow transplantation. Bone Marrow Transplant 1996; 18:397-403.

16 Frankel W, Chan A, Corringham RE, Shepherd $\mathrm{S}$, Rearden A, Wang-Rodriguez J: Detection of chimerism and early engraftment after allogeneic peripheral blood stem cell or bone marrow transplantation by short tandem repeats. Am J Hematol 1996;52/4:281-287.
17 Cheson BD, Cassileth PA, Head DR, Schiffer CA, Bennett JM, Bloomfield CD, Brunning R, Gale RP, Grever MR, Keating MJ: Report of the National Cancer Institute-sponsored workshop on definitions of diagnosis and response in acute myeloid leukemia. J Clin Oncol 1990; 8:813-819.

18 Gozzetti A, Le Beau MM: Fluorescence in situ hybridization: Uses and limitations. Semin Hematol 2000;37:320-333.

19 Kern W, Danhauser-Riedl S, Ratei R, Schnittger S, Schoch C, Kolb HJ, Ludwig WD, Hiddemann W, Haferlach T: Detection of minimal residual disease in unselected patients with acute myeloid leukemia using multiparameter flow cytometry for definition of leukemia-associated immunophenotypes and determination of their frequencies in normal bone marrow. Haematologica 2003;88:646-653.

20 Borowitz MJ, Pullen DJ, Shuster JJ, Viswanatha D, Montgomery K, Willman CL, Camitta $\mathrm{B}$ : Minimal residual disease detection in childhood precursor-B-cell acute lymphoblastic leukemia: Relation to other risk factors. A Children's Oncology Group study. Leukemia 2003; 17:1566-1572.

21 Basecke J, Griesinger F, Trumper L, Brittinger G: Leukemia- and lymphoma-associated genetic aberrations in healthy individuals. Ann Hematol 2002;81/2:64-75.

22 van der Velden V, Hochhaus A, Cazzaniga G, Szczepanski T, Gabert J, van Dongen JJ: Detection of minimal residual disease in hematologic malignancies by real-time quantitative PCR: Principles, approaches, and laboratory aspects. Leukemia 2003; 17:1013-1034.

23 Fehse B, Chukhlovin A, Kuhlcke K, Marinetz O, Vorwig O, Renges H, Kruger W, Zabelina T, Dudina O, Finckenstein FG, Kroger N, Kabisch H, Hochhaus A, Zander AR: Real-time quantitative $\mathrm{Y}$ chromosome-specific PCR (QYCS-PCR) for monitoring hematopoietic chimerism after sex-mismatched allogeneic stem cell transplantation. J Hematother Stem Cell Res 2001;10:419-425. 
24 Alizadeh AA, Eisen MB, Davis RE, Ma C, Lossos IS, Rosenwald A, Boldrick JC, Sabet H, Tran T, Yu X, Powell JI, Yang L, Marti GE, Moore T, Hudson J Jr, Lu L, Lewis DB, Tibshirani $\mathrm{R}$, Sherlock $\mathrm{G}$, Chan WC, Greiner TC, Weisenburger DD, Armitage JO, Warnke R, Staudt LM: Distinct types of diffuse large B-cell lymphoma identified by gene expression profiling. Nature 2000;403:503-511.

25 Maas F, Schaap N, Kolen S, Zoetbrood A, Buno I, Dolstra H, de Witte T, Schattenberg A, van De Wiel-van Kemenade E: Quantification of donor and recipient hemopoietic cells by real-time PCR of single nucleotide polymorphisms. Leukemia 2003; 17:621-629.

26 Schaap N, Schattenberg A, Bar B, Mensink E, de Man A, Geurts van Kessel A, de Witte T: Red blood cell phenotyping is a sensitive technique for monitoring chronic myeloid leukaemia patients after T-cell-depleted bone marrow transplantation and after donor leucocyte infusion. Br J Haematol 2000;108/1:116125.

27 Kogler G, Wolf HH, Heyll A, Arkesteijn G, Wernet P: Detection of mixed chimerism and leukemic relapse after allogeneic bone marrow transplantation in subpopulations of leucocytes by fluorescent in situ hybridization in combination with the simultaneous immunophenotypic analysis of interphase cells. Bone Marrow Transplant 1995;15/1:41-48.

28 van Tol MJ, Langlois van den Bergh R, Mesker W, Ouwerkerk-van Velzen MC, Vossen JM, Tanke HJ: Simultaneous detection of $X$ and $Y$ chromosomes by two-colour fluorescence in situ hybridization in combination with immunophenotyping of single cells to document chimaerism after sex-mismatched bone marrow transplantation. Bone Marrow Transplant 1998;21:497-503.

29 Cotteret S, Belloc F, Boiron JM, Bilhou-Nabera C, Dumain P, Boyer C, Lacombe F, Reiffers J, Bernard P: Fluorescent in situ hybridization on flow-sorted cells as a tool for evaluating minimal residual disease or chimerism after allogenic bone marrow transplantation. Cytometry 1998;34/5:216-222.

30 Baurmann H, Nagel S, Binder T, Neubauer A, Siegert W, Huhn D: Kinetics of the graft-versus-leukemia response after donor leukocyte infusions for relapsed chronic myeloid leukemia after allogeneic bone marrow transplantation. Blood 1998;92:3582-3590.

31 van Leeuwen JE, van Tol MJ, Joosten AM, Wijnen JT, Verweij PJ, Khan PM, Vossen JM: Persistence of host-type hematopoiesis after allogeneic bone marrow transplantation for leukemia is significantly related to the recipient's age and/or the conditioning regimen, but it is not associated with an increased risk of relapse. Blood 1994;83:3059-3067.

32 Gardiner N, Lawler M, O'Riordan JM, Duggan C, De Arce M, McCann SR: Monitoring of lineage-specific chimaerism allows early prediction of response following donor lymphocyte infusions for relapsed chronic myeloid leukaemia. Bone Marrow Transplant 1998;21: 711-719.
33 Thiede C, Bornhäuser M, Oelschlägel U, Brendel C, Leo R, Daxberger H, Mohr B, Florek M, Kroschinsky F, Geissler G, Naumann R, Ritter M, Prange-Krex G, Lion T, Neubauer A, Ehninger G: Sequential monitoring of chimerism and detection of minimal residual disease after allogeneic blood stem cell transplantation (BSCT) using multiplex PCR amplification of short tandem repeat-markers. Leukemia 2001; 15/2:293-302.

34 Mattsson J, Uzunel M, Tammik L, Aschan J, Ringden O: Leukemia lineage-specific chimerism analysis is a sensitive predictor of relapse in patients with acute myeloid leukemia and myelodysplastic syndrome after allogeneic stem cell transplantation. Leukemia 2001;15: 1976-1985.

35 Roman J, Martin C, Torres A, Garcia A, Andres P, Garcia MJ, Baiget M: Importance of mixed chimerism to predict relapse in persistently BCR/ABL positive long survivors after allogeneic bone marrow transplantation for chronic myeloid leukemia. Leuk Lymphoma 1998;28:541-550.

36 Serrano J, Roman J, Sanchez J, Jimenez A, Castillejo JA, Herrera C, Gonzalez MG, Reina L, Rodriguez MC, Alvarez MA, Maldonado J, Torres A: Molecular analysis of lineage-specific chimerism and minimal residual disease by RT-PCR of p210(BCR-ABL) and p190(BCR$\mathrm{ABL}$ ) after allogeneic bone marrow transplantation for chronic myeloid leukemia: Increasing mixed myeloid chimerism and p190(BCRABL) detection precede cytogenetic relapse. Blood 2000;95:2659-2665.

37 Eder M, Battmer K, Kafert S, Stucki A, Ganser A, Hertenstein B: Monitoring of BCR-ABL expression using real-time RT-PCR in CML after bone marrow or peripheral blood stem cell transplantation. Leukemia 1999;13:13831389.

38 Kaeda J, Chase A, Goldman JM: Cytogenetic and molecular monitoring of residual disease in chronic myeloid leukaemia. Acta Haematol 2002;107/2:64-75.

39 Keil F, Haas OA, Fritsch G, Kalhs P, Lechner K, Mannhalter C, Reiter E, Niederwieser D, Hoecker P, Greinix HT: Donor leukocyte infusion for leukemic relapse after allogeneic marrow transplantation: Lack of residual donor hematopoiesis predicts aplasia. Blood 1997;89: 3113-3117.

40 Passweg JR, Meyer-Monard S, Gregor M, Favre G, Heim D, Ebnoether M, Tichelli A, Gratwohl A: High stem cell dose will not compensate for $\mathrm{T}$ cell depletion in allogeneic nonmyeloablative stem cell transplantation. Bone Marrow Transplant 2002;30:267-271.

41 Bader P, Holle W, Klingebiel T, Handgretinger $\mathrm{R}$, Benda N, Schlegel PG, Niethammer D, Beck J: Mixed hematopoietic chimerism after allogeneic bone marrow transplantation: The impact of quantitative PCR analysis for prediction of relapse and graft rejection in children. Bone Marrow Transplant 1997;19:697-702.
42 Bader P, Beck J, Frey A, Schlegel PG, Hebarth $\mathrm{H}$, Handgretinger R, Einsele $\mathrm{H}$, Niemeyer $\mathrm{C}$, Benda N, Faul C, Kanz L, Niethammer D, Klingebiel T: Serial and quantitative analysis of mixed hematopoietic chimerism by PCR in patients with acute leukemias allows the prediction of relapse after allogeneic BMT. Bone Marrow Transplant 1998;21:487-495.

43 de Weger RA, Tilanus MG, Scheidel KC, van den Tweel JG, Verdonck LF: Monitoring of residual disease and guided donor leucocyte infusion after allogeneic bone marrow transplantation by chimaerism analysis with short tandem repeats. Br J Haematol 2000;1 10:647-653.

44 Barrios M, Jimenez-Velasco A, Roman-Gomez J, Madrigal ME, Castillejo JA, Torres A, Heiniger A: Chimerism status is a useful predictor of relapse after allogeneic stem cell transplantation for acute leukemia. Haematologica 2003. 88:801-810.

45 Bertheas MF, Lafage M, Levy P, Blaise D, Stoppa AM, Viens P, Mannoni P, Maraninchi $\mathrm{D}$ : Influence of mixed chimerism on the results of allogeneic bone marrow transplantation for leukemia. Blood 1991;78:3103-3106.

46 Molloy K, Goulden N, Lawler M, Cornish J, Oakhill A, Pamphilon D, Potter M, Steward C, Langlands K, Humphries P, McCann SR: Patterns of hematopoietic chimerism following bone marrow transplantation for childhood acute lymphoblastic leukemia from volunteer unrelated donors. Blood 1996;87:3027-3031.

47 Miflin G, Stainer CJ, Carter GI, Byrne JL, Haynes AP, Russell NH: Comparative serial quantitative measurements of chimaerism following unmanipulated allogeneic transplantation of peripheral blood stem cells and bone marrow. Br J Haematol 1999; 107:429-440.

48 Choi SJ, Lee KH, Lee JH, Kim S, Chung HJ, Lee JS, Kim SH, Park CJ, Chi HS, Kim WK: Prognostic value of hematopoietic chimerism in patients with acute leukemia after allogeneic bone marrow transplantation: A prospective study. Bone Marrow Transplant 2000;26:327332.

49 Butler JM: Biology of STRs: Stutter products, non-template addition, microvariants, null alleles, and mutation rates; in Butler JM (ed): Forensic DNA Typing - Biology and Technology behind STR markers. London, Academic Press, 2001, pp 81-98.

50 Nollet F, Billiet J, Selleslag D, Criel A: Standardisation of multiplex fluorescent short tandem repeat analysis for chimerism testing. Bone Marrow Transplant 2001;28:511-518.

50a Thiede C, Bornhäuser M, Ehninger G: Evaluation of STR informativity for chimerism testing - comparative analysis of 27 STR systems in 203 matched related donor recipient pairs. Leukemia 2004;18(2):248-254.

51 Lo YM, Tein MS, Lau TK, Haines CJ, Leung TN, Poon PM, Wainscoat JS, Johnson PJ, Chang AM, Hjelm NM: Quantitative analysis of fetal DNA in maternal plasma and serum: Implications for noninvasive prenatal diagnosis. Am J Hum Genet 1998;62:768-775. 
52 Thiede C, Kellermann T, Schwerdtfeger R, Baurmann H, Steudel C, Ehninger G, Bornhäuser M: Real-time PCR for the SRY-gene allows sensitive and quantitative chimerism analysis after allogeneic blood stem cell transplantation: Clinical results in 43 patients (abstract). Bone Marrow Transplant 2003;31 (suppl 1):S23-A181.

53 Mangioni S, Balduzzi A, Rivolta A, Rovelli A, Nesi F, Rossi V, Busca A, Uderzo C, Miniero $\mathrm{R}$, Biondi A: Long-term persistence of hemopoietic chimerism following sex-mismatched bone marrow transplantation. Bone Marrow Transplant 1997;20:969-973.

54 Alizadeh M, Bernard M, Danic B, Dauriac C, Birebent B, Lapart C, Lamy T, Le Prise PY, Beauplet A, Bories D, Semana G, Quelvennec E: Quantitative assessment of hematopoietic chimerism after bone marrow transplantation by real-time quantitative polymerase chain reaction. Blood 2002;99:4618-4625.

55 Thiede C, Florek M, Bornhäuser M, Ritter M, Mohr B, Brendel C, Ehninger G, Neubauer A: Rapid quantification of mixed chimerism using multiplex amplification of short tandem repeat markers and fluorescence detection. Bone Marrow Transplant 1999;23:1055-1060.

56 Ault KA, Antin JH, Ginsburg D, Orkin SH, Rappeport JM, Keohan ML, Martin P, Smith BR: Phenotype of recovering lymphoid cell populations after marrow transplantation. $\mathbf{J}$ Exp Med 1985;161:1483-1502.

57 van Leeuwen JE, van Tol MJ, Bodzinga BG, Wijnen JT, van der KM, Joosten AM, Tanke HJ, Vossen JM, Khan PM: Detection of mixed chimaerism in flow-sorted cell subpopulations by PCR-amplified VNTR markers after allogeneic bone marrow transplantation. $\mathrm{Br} \mathrm{J} \mathrm{Hae}-$ matol 1991;79:218-225.
58 Lamb LS Jr, Robbins NF, Abhyankar S, Joyce M, Stetler-Stevenson M, Henslee-Downey PJ, Gee AP: Flow cytometric cell sorting combined with molecular chimerism analysis to detect minimal recurrent leukemia: Good news and bad news. Bone Marrow Transplant 1997;19: 1157-1161.

59 Winiarski J, Gustafsson A, Wester D, Dalianis $\mathrm{T}$ : Follow-up of chimerism, including T- and B-lymphocytes and granulocytes in children more than one year after allogeneic bone marrow transplantation. Pediatr Transplant 2000; 4/2:132-139.

60 Zetterquist H, Mattsson J, Uzunel M, NasmanBjork I, Svenberg P, Tammik L, Bayat G, Winiarski J, Ringden O: Mixed chimerism in the $B$ cell lineage is a rapid and sensitive indicator of minimal residual disease in bone marrow transplant recipients with pre-B cell acute lymphoblastic leukemia. Bone Marrow Transplant 2000;25:843-851.

61 Thiede C, Lutterbeck K, Oelschlägel U, Kiehl M, Steudel C, Platzbecker U, Brendel C, Fauser AA, Neubauer A, Ehninger G, Bornhauser $\mathrm{M}$ : Detection of relapse by sequential monitoring of chimerism in circulating CD34+ cells. Ann Hematol 2002;81(suppl 2):S27-S28.

62 Maynadie M, Gerland L, Aho S, Girodon F, Bernier M, Brunet C, Campos L, Daliphard S, Deneys V, Falkenrodt A, Jacob MC, Kuhlein E, LeCalvez G, Moskovtchenko P, Philip P, Carli PM, Faure GC, Bene MC: Clinical value of the quantitative expression of the three epitopes of CD34 in 300 cases of acute myeloid leukemia. Haematologica 2002;87:795-803.

63 Serke S, Huhn D: Expression of class I, II and III epitopes of the CD34 antigen by normal and leukemic hemopoietic cells. Cytometry 1996; 26/2:154-160.
64 Schraml E, Daxberger H, Watzinger F, Lion T: Quantitative analysis of chimerism after allogeneic stem cell transplantation by PCR amplification of microsatellite markers and capillary electrophoresis with fluorescence detection: The Vienna experience. Leukemia 2003; 17/1:224-227.

65 Chalandon Y, Vischer S, Helg C, Chapuis B, Roosnek E: Quantitative analysis of chimerism after allogeneic stem cell transplantation by PCR amplification of microsatellite markers and capillary electrophoresis with fluorescence detection: The Geneva experience. Leukemia 2003; 17/1:228-231.

66 Koehl U, Beck O, Esser R, Seifried E, Klingebiel T, Schwabe D, Seidl C: Quantitative analysis of chimerism after allogeneic stem cell transplantation by PCR amplification of microsatellite markers and capillary electrophoresis with fluorescence detection: The Frankfurt experience. Leukemia 2003;17/1:232-236.

67 Kreyenberg H, Holle W, Mohrle S, Niethammer D, Bader P: Quantitative analysis of chimerism after allogeneic stem cell transplantation by PCR amplification of microsatellite markers and capillary electrophoresis with fluorescence detection: The Tuebingen experience. Leukemia 2003;17/1:237-240.

68 Acquaviva C, Duval M, Mirebeau D, Bertin R, Cave H: Quantitative analysis of chimerism after allogeneic stem cell transplantation by PCR amplification of microsatellite markers and capillary electrophoresis with fluorescence detection: The Paris-Robert Debre experience. Leukemia 2003;17/1:241-246.

69 Hancock JP, Goulden NJ, Oakhill A, Steward CG: Quantitative analysis of chimerism after allogeneic bone marrow transplantation using immunomagnetic selection and fluorescent microsatellite PCR. Leukemia 2003;17/1:247251. 